
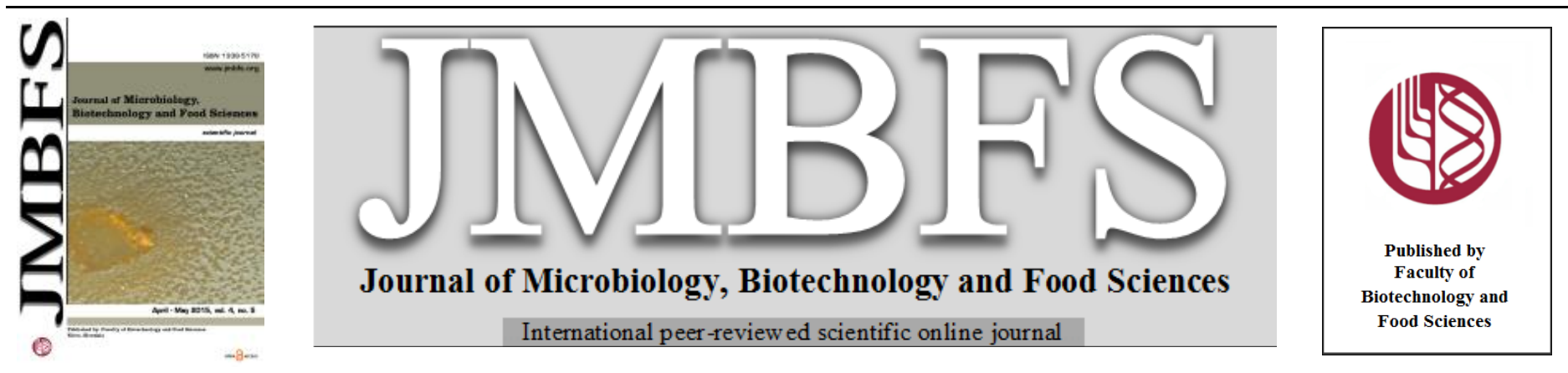

\title{
IMPROVEMENT OF NUTRITIONAL AND HEALTHY VALUES OF YOGHURT BY FORTIFICATION WITH RUTUB DATE
}

\section{Magdy M. Ismail}

\author{
Address(es): \\ Dairy Technology Department, Animal Production Research Institute, Agricultural Research Center, Dokki, Giza, Egypt.
}

*Corresponding author: abo-omar98@hotmail.com

doi: 10.15414/jmbfs.2015.4.5.398-406

\section{ARTICLE INFO}

Received 5. 11. 2014

Revised 16. 1. 2015

Accepted 24. 1.2015

Published 1. 4. 2015

Regular article open $\partial$ access

\begin{abstract}
As is well known, the date fruits are good sources of many nutrients. Also, yoghurt especially bio-yoghurt has a lot of nutritional and healthy benefits. The aim of this study was to combine the benefits of date and bio-yoghurt in one product which can be made by simple manner. Six treatments of yoghurt were made from cow's milk fortified with 10 and $15 \%$ rutub date and using classic or ABT-5 cultures. Changes in rheological, chemical, microbial and organoleptic properties of yoghurt were monitored during refrigerated storage $\left(4^{\circ} \mathrm{C}\right)$ of yoghurt for $15 \mathrm{~d}$. Results showed that fortification with date accelerates the rates of fermentation and lowered coagulation time. For rheological analyses, curd tension, viscosity and water holding capacity values increased whereas curd syneresis values decreased in bio-yoghurt fortified with date. Redox potential values were lower in date yoghurt as compared with control. Acidity, carbohydrate, total solids, dietary fiber and ash contents of yoghurt supplemented with date were higher than those of control. Supplementation of date increased mineral contents $(\mathrm{K}, \mathrm{Ca}, \mathrm{P}, \mathrm{Mg}, \mathrm{Na}$ and $\mathrm{Fe}$ ), total nitrogen, water soluble nitrogen, total phenols and total volatile fatty acids of yoghurt. The addition of date improved the viability of lactic acid bacteria and bifidobacteria. The bifidobacteria counts were sufficient to yield numbers of beneficial organisms that were higher than the accepted threshold $\left(10^{6} \mathrm{cfu}_{\mathrm{g}} \mathrm{g}^{-1}\right)$ for a probiotic effect. Also, date adding improved the body, texture and flavor of the yoghurt.
\end{abstract}

Keywords: ABT, yoghurt, bifidobacteria, rutub date

\section{INTRODUCTION}

During the last 35 years, attempts have been made to improve the health status of human by modulating the intestinal microflora using live microbial adjuncts called probiotics. Indeed, different products containing probiotic bacteria have gained in popularity with consumers. Strains of Lactobacillus acidophilus and Lactobacillus casei complex are well represented in commercial probiotic products, followed by Bifidobacterium spp. (Denis, 2005).

Yoghurt is increasingly seen as a safe and enjoyable means to deliver probiotics to the gut, in which case patients and healthy individuals alike will benefit from both the rich nutrients and probiotic content. Certain species, particularly lactic acid bacteria, are used in yoghurt manufacture. Basically, for a product to be called yoghurt in North America, it must be fermented with a symbiotic blend of Streptococcus salivarius subsp. thermophilus and L. delbrueckii subsp. bulgaricus. These two species are commonly referred to as yoghurt bacteria. These symbiotic bacteria do not however adequately survive gastric passage or colonize the gut, thus necessitating the addition of other LAB species in yoghurt preparations: L. acidophilus, L. casei, $\quad$ B. bifi dum, B. logum, B. breve, $B$. infantis, and B. lactis, and others (Cogan et al., 2007). These microorganisms are capable of partially resisting gastric and bile secretions in vitro and in vivo and can deliver enzymes and other substances into the intestines (Alvaro et al., 2007).

On the other hand, date represents one of the most important fruit crops in Egypt and Arab world. It is eaten at all stages of the fruit development (khalal, rutub, and tamr). In addition to direct consumption, dates are processed in many ways, including the production of date paste and date syrup, depis. Date paste and depis are incorporated in several products including jam, preserve, jelly and date bars (Yousif, 1995). Egypt is the first leading country worldwide for date production, producing 1.373 .570 tonnes of dates in 2011, representing $20 \%$ of the world's production (FAOSTAT, 2013).

The fruit of the dates are good sources of sugars, vitamin C, provitamin A, minerals (excellent source of potassium) and fibers (El-Sohaimy and Hafez, 2010). Consumption of dates may benefit in glycaemic and lipid control of diabetic patients (Miller et al., 2003). Lately, several therapeutic virtues are assigned to the date palm and its derivatives. Date fruit has anti-tumor activity antioxidant and anti-mutagenic properties (Mansouri et al., 2005). The fruit has been recommended in folk remedies for the treatment of various infectious diseases and cancers (Duke, 1992). Dry date fruits are used in Indian traditional medicine after child birth as immunostimulants. Extracts of the dates provided to the women after childbirth stimulate their immune system (Puri et al., 2000). Usually, fruit flavored yoghurt is prepared by using yoghurt bacteria starter, so the present study was designed to use ABT culture in manufacture yoghurt fortified with different levels of rutub date with whole cow milk to be a combination of biological benefits of both probiotic bacteria and dates.

\section{MATERIALS AND METHODS}

\section{Starter Cultures and rutub dates}

In the present study, a commercial yoghurt starter containing Streptococcus salivarius subsp. thermophillus and Lactobacillus delbruckii subsp. bulgaricus (1:1) and ABT culture (ABT-5) with mixed strains of $S$. thermophilus (as sole fermenting organism) and LA $+B$. bifidum (as probiotic organisms) (Chr. Hansen's Lab A/S Copenhagen, Denmark) were used. The starter culture was in freeze-dried direct-to-vat set form. After procurement, the starter cultures were stored at $-18^{\circ} \mathrm{C}$ in the absence of atmospheric air. Fresh rutub (wet) dates (Phoenix dactylifera L.) were obtained from local market in Damiette Governorate, Egypt. The used dates flesh had $\mathrm{pH} 7.11$, moisture $42.78 \%$, protein $2.56 \%$, fat $0.2 \%$, total sugar $49.32 \%$, ash $2.11 \%$, and crude fiber $3.21 \%$.

\section{Yoghurt Preparation}

Preliminary trials were conducted to prepare yoghurt supplemented with date pieces similar to the commercial flavored yoghurt and to determine the highest levels of date products to be added.

Yoghurt samples were prepared from fresh cow's milk (acidity $0.16 \%, \mathrm{pH} 6.61$, fat 4.4, TS 13.09 and total protein 3.28\%) in Dairy Laboratory of El-Serw Animal Production Research Station, Animal Production Research Institute, Agricultural Research Center. Six yoghurt treatments were made using classic yoghurt bacteria or ABT cultures. The first three yoghurt samples were 
manufactured using classic starter whereas the other three treatments were made by $\mathrm{ABT}$ culture. Cow's milk was tempered to $50^{\circ} \mathrm{C}$ and fortified with 0 (control), 10 and $15 \%(\mathrm{w} / \mathrm{w})$ rutub dates pieces with adding stabilizer $(0.5 \%)$. The mixture was blended at $2000 \mathrm{rpm}$ for $3 \mathrm{~min}$, reheated to $90^{\circ} \mathrm{C}$ for $15 \mathrm{~min}$, cooled to $42^{\circ} \mathrm{C}$, inoculated with cultures $\left(0.1\right.$ g. $\mathrm{L}^{-1}$ of yoghurt mix), transferred to $100-\mathrm{ml}$ plastic cups, incubated at $42^{\circ} \mathrm{C}$ for fully coagulation, and stored at $4{ }^{\circ} \mathrm{C}$ for 15 days Yoghurt samples were analyzed in fresh and after 7 and 15 days of refrigerated storage. Three replicates of each treatment were conducted.

\section{Chemical Analyses}

Total solids, fat, total nitrogen and ash contents of samples were determined according to (AOAC, 2000). Titratable acidity in terms of \% lactic acid was measured by titrating $10 \mathrm{~g}$ of sample mixed with $10 \mathrm{ml}$ of boiling distilled water against $0.1 \mathrm{~N} \mathrm{NaOH}$ using a $0.5 \%$ phenolphthalein indicator to an end point of faint pink color. $\mathrm{pH}$ of the sample was measured at 17 to $20^{\circ} \mathrm{C}$ using a $\mathrm{pH}$ meter (Corning $\mathrm{pH} /$ ion analyzer 350, Corning, NY) after calibration with standard buffers $(\mathrm{pH} 4.0$ and 7.0). Redox potential was measured with a platinum electrode [model P14805-SC-DPAS-K8S/325; Ingold (now Mettler Toledo) Urdorf, Switzerland] connected to a $\mathrm{pH}$ meter (model $\mathrm{H}$ 18418; Hanna Instruments, Padova, Italy). Water soluble nitrogen (WSN) of yoghurt was estimated according to Ling (1963). Total volatile fatty acids (TVFA) were determined according to Kosikowiski (1978). Total dietary fiber (TDF) was calculated as described by AOAC (2005). The method of Zheng and Wang (2001) was followed in determining the total phenol compounds in yoghurt using Folin Ciocalteu Reagent (FCR) and gallic acid as a standard solution. Minerals ( $\mathrm{Na}, \mathrm{K}, \mathrm{Ca}, \mathrm{Mg}, \mathrm{P}, \mathrm{Fe}$ ) content of the yoghurt was determined by atomic absorption spectrophotometer (Varian spectra AA 220) (Tamimea et al., 1999). Carbohydrate content was done according to Ellefson et al. (2005).

\section{Rheological Propertie}

Viscosity was measured after $24 \mathrm{hr}$ at $25{ }^{\circ} \mathrm{C} \pm 0.5$ at 50rpm using $\mathrm{RV}$ spindle No.3 (DV-II + Viscometer Brookfield Engineering Labs. Inc. Middle Boro, MA02346, USA).

The curd tension was determined using the method of Chandrasekhara $\boldsymbol{e t} \boldsymbol{a l}$, (1957) whereas the curd syneresis was measured as given by Mehanna and Mehanna (1989). For test of starter coagulation time during yoghurt making, milk was inculcated with starts and incubated at $40^{\circ} \mathrm{C}$ then coagulation was noticed at 30 min intervals.

Water holding capacity (WHC) was measured according to Yousef $\boldsymbol{e t}$ al. (2013). Twenty g sample of native yoghurt (NY) was centrifuged for $10 \mathrm{~min}$ at $669 \mathrm{~g}$ and supernatant was removed and weighted (whey expelled (WE)). The WHC \% was defined as:

\section{Microbiological Analyses}

$$
\text { WHC }(\%)=100 \times \text { NY-WE/NY }
$$

Yoghurt samples were analyzed for total viable bacterial count (TVBC), lactic acid bacteria (LAB), coliform bacteria, moulds and yeast counts according to the methods described by the American Public Health Association (1992). The count of bifidobacteria was determined according to Dinakar and Mistry (1994). A mixture of antibiotics, including $2 \mathrm{~g}$ of neomycin sulfate, $4 \mathrm{~g}$ of paromomycin sulfate, $0.3 \mathrm{~g}$ of nalidixic acid, and $60 \mathrm{~g}$ of lithium chloride (NPNL, Sigma Chemical Co.), was prepared in $1 \mathrm{~L}$ of distilled water, filtersterilized, and stored at $4{ }^{\circ} \mathrm{C}$ until use. The mixture of antibiotics $(5 \mathrm{ml})$ was added to $100 \mathrm{ml}$ of MRS agar medium. Cysteine-HC1 was added at the rate of $0.05 \%$ to decrease the redox potential of the medium. Plates were incubated at $37^{\circ} \mathrm{C}$ for 48 to $72 \mathrm{~h}$ under anaerobic condition.

\section{Organoleptic Analyses}

Samples of yoghurt were organoleptically scored by the staff of the El-Serw Animal Production Research Station. The score points were 50 for flavour, 35 for body and texture and 15 for colour and appearance, which give a total score of 100 points.

\section{Statistical Analysis}

The obtained results were statistically analyzed using a software package (SAS 1991) based on analysis of variance. When F-test was significant, least significant difference (LSD) was calculated according to Duncan (1955) for the comparison between means. The data presented, in the tables, are the mean $( \pm$ standard deviation) of 3 experiments.

\section{RESULTS AND DISCUSSION}

\section{Changes in acidity during fermentation of yoghurt mix for $180 \mathrm{~min}$}

For measurement of starter activity as affected by adding 10 and $15 \%$ rutub dates, the changes of acidity (as lactic acid percentages) and $\mathrm{pH}$ values of cow's milk inoculated with classic yoghurt and ABT cultures was determined at $30 \mathrm{~min}$ intervals till $180 \mathrm{~min}$. Results were illustrated in Table 1. As it is expected, a gradual increase of titratable acidity values in control and all samples was noticed during incubation for $180 \mathrm{~min}$. The highest increasing was found after $90 \mathrm{~min}$. Both acidity ratios and the development of acidity rats within fermentation were a little bit higher in milk inoculated with classic starter (treatment A) than that of milk inoculated with ABT culture (treatment D). Values of $\mathrm{pH}$ had the opposite trend of acidity. These outcomes are similar to that reported by Damin et al., (2008) who stated that milk fermented with Streptococcus thermophilus and Bifidobacterium lactis had the lowest post acidification. This behavior could be explained by the limited capacity of bifidobacterium to produce organic acids at low temperatures (Mattila-Sandholm et al., 2002) or by the highly proteolytic activity of normal starter which could produce higher amount of proteinase enzymes which breakdown milk protein into small peptides that are used as a nitrogen source during the growth of the cells in milk (Thomas and Pritchard, 1987). This in turn would lead to higher growth and acidification rate in milk. Samples of yoghurt with added dates to milk showed a pronounced rising in titratable acidity during the $180 \mathrm{~min}$ of fermentation, also, an increase in the concentration of dates positively affected the rate of acid production. This may be attributed to the activation of starter bacteria by the dates added. Confirming to theses results, it could be observed from Table 5 that yoghurt samples fortified with dates contained higher count of lactic acid bacteria than that of control one.

Table 1 Effect of adding of rutub dates to cow's milk on starter activity (expressed as acidity $\%$ and $\mathrm{pH}$ values) (means $\pm \mathrm{SD}$ )

\begin{tabular}{|c|c|c|c|c|c|c|c|c|c|}
\hline \multirow[t]{2}{*}{ Properties } & \multirow[t]{2}{*}{ Treatments } & \multicolumn{7}{|c|}{ Incubation time (min) } & \multirow[t]{2}{*}{ Means \pm SD } \\
\hline & & 0 & 30 & 60 & 90 & 120 & 150 & 180 & \\
\hline \multirow{7}{*}{$\begin{array}{l}\text { Acidity } \\
(\%)\end{array}$} & $\mathrm{A}$ & 0.17 & 0.18 & 0.22 & 0.27 & 0.38 & 0.45 & 0.53 & $0.31 \pm 0.13^{b}$ \\
\hline & B & 0.18 & 0.20 & 0.25 & 0.31 & 0.40 & 0.48 & 0.55 & $0.34 \pm 0.14^{\mathrm{b}}$ \\
\hline & $\mathrm{C}$ & 0.19 & 0.21 & 0.27 & 0.32 & 0.42 & 0.49 & 0.56 & $0.35 \pm 0.15^{\mathrm{a}}$ \\
\hline & D & 0.16 & 0.17 & 0.20 & 0.25 & 0.35 & 0.40 & 0.46 & $0.28 \pm 0.11^{\mathrm{b}}$ \\
\hline & $\mathrm{E}$ & 0.17 & 0.19 & 0.22 & 0.27 & 0.38 & 0.42 & 0.49 & $0.30 \pm 0.12^{\mathrm{b}}$ \\
\hline & $\mathrm{F}$ & 0.18 & 0.21 & 0.25 & 0.30 & 0.40 & 0.46 & 0.50 & $0.32 \pm 0.12^{\mathrm{b}}$ \\
\hline & Means \pm SD & $\begin{array}{c}0.17 \pm 0.02 \\
7^{\mathrm{A}}\end{array}$ & $\begin{array}{c}0.19 \pm 0.02 \\
9^{\mathrm{A}}\end{array}$ & $\begin{array}{c}0.230 \pm .02 \\
7^{\mathrm{A}}\end{array}$ & $\begin{array}{c}0.28 \pm 0.02 \\
8^{\mathrm{A}}\end{array}$ & $\begin{array}{c}0.39 \pm 0.02 \\
7^{\mathrm{A}}\end{array}$ & $\begin{array}{c}0.45 \pm 0.03 \\
5^{\mathrm{A}}\end{array}$ & $\begin{array}{c}0.51 \pm 0.03 \\
8^{\mathrm{A}}\end{array}$ & \\
\hline \multirow{7}{*}{$\mathrm{pH}$} & A & 6.60 & 6.56 & 6.44 & 6.31 & 6.06 & 5.85 & 5.68 & $6.21 \pm 0.34^{\mathrm{b}}$ \\
\hline & B & 6.57 & 6.50 & 6.39 & 6.25 & 5.98 & 5.76 & 5.60 & $6.15 \pm 0.36^{\mathrm{c}}$ \\
\hline & $\mathrm{C}$ & 6.54 & 6.46 & 6.32 & 6.23 & 5.93 & 5.74 & 5.58 & $6.11 \pm 0.35^{\mathrm{d}}$ \\
\hline & D & 6.63 & 6.59 & 6.52 & 6.42 & 6.17 & 5.97 & 5.84 & $6.30 \pm 0.30^{\mathrm{a}}$ \\
\hline & $\mathrm{E}$ & 6.60 & 6.53 & 6.43 & 6.30 & 6.07 & 5.92 & 5.75 & $6.23 \pm 0.31^{\mathrm{b}}$ \\
\hline & $\mathrm{F}$ & 6.55 & 6.45 & 6.39 & 6.28 & 5.96 & 5.83 & 5.71 & $6.17 \pm 0.31^{\mathrm{c}}$ \\
\hline & Means \pm SD & $\begin{array}{c}6.58 \pm 0.03 \\
8^{\mathrm{A}}\end{array}$ & $\begin{array}{c}6.51 \pm 0.05 \\
6^{\mathrm{B}}\end{array}$ & $\begin{array}{c}6.41 \pm 0.06 \\
7^{\mathrm{C}}\end{array}$ & $\begin{array}{c}6.30 \pm 0.06 \\
6^{\mathrm{D}}\end{array}$ & $\begin{array}{c}6.03 \pm 0.08 \\
7^{\mathrm{E}}\end{array}$ & $\begin{array}{c}5.84 \pm 0.08 \\
8^{\mathrm{F}}\end{array}$ & $\begin{array}{c}5.69 \pm 0.09 \\
4^{\mathrm{G}}\end{array}$ & \\
\hline
\end{tabular}

\section{${ }_{\text {abcde }}$ Letters indicate significant differences between Labneh treatments}

${ }_{\mathrm{ABCD}}$ Letters indicate significant differences between storage times

A- Yoghurt made using classic starter (Streptococcus thermophillus and Lactobacillus bulgaricus)

B- Yoghurt made using classic starter $+10 \%$ rutub dates

C- Yoghurt made using classic starter $+15 \%$ rutub dates

D- Yoghurt made using ABT

E- Yoghurt made using ABT $+10 \%$ rutub dates

F- Yoghurt made using $\mathrm{ABT}+15 \%$ rutub dates 


\section{Changes in rheological properties of yoghurt}

Table 2 presented the effect of using ABT culture and adding different levels of rutub dates to cow milk on coagulation time, viscosity, curd tension and water holding capacity (WHC) of the produced yoghurt whereas Table 3 showed the syneresis values. The contribution of bifidobacteria with yoghurt culture has changed the rheological attitude. Coagulation time of control treatment (A) was $180 \mathrm{~min}$. and increased to $210 \mathrm{~min}$. as result of using ABT culture in yoghurt manufacture (treatment D). These results may be attributed to the slow acid production of ABT starter as compared with that of classic yoghurt. Saccaro et al., (2009) found that growth of probiotic strains, when grown singly or blends with yoghurt cultures affected the fermentation time and the rate of acidification. Many other researchers have also reported that probiotic bacteria have a poor acidification performance in milk when compared to a yoghurt starter culture (Almeida et al., 2008). On the contrary of coagulation time results, viscosity and curd tension values were lower for ABT yoghurt as compared with those of control. Those data indicate that the curd of ABT yoghurt was softer than that of classic one.

Syneresis is the losing out of liquid from yoghurt. It is one of the key quality parameters for yoghurt. In the present study syneresis was measured by means of both centrifugal and drainage methods. The results of centrifugal method showed that ABT yoghurt exhibited the lowest water holding capacity. Control yoghurt exhibited greater ability to bind water than bio-yoghurt. In the drainage method, ABT yoghurt had higher curd syneresis values than those of classic starter one. Conversely, Hussein (2010) stated that increased separation of whey was found from the infants' yoghurt-like fermented products (IYFP) made with traditional starter than that made with probiotic starter (ABT-2).

On the other hand, blending of dates with milk caused significantly $(\mathrm{P}<0.05)$ decrease in coagulation time of yoghurt. Kale et al. (2011) reported that fortification of cow milk with different levels of date palm paste reduced the setting time of yoghurt. Because adding dates raised the total solids content of milk (Table 4), the produced yoghurt had the highest values of viscosity and curd tension comparing with control. Similar observations for viscosity were found by Keshtkaran and Mohammadifar (2013), with regard to date milk beverages with different levels of date syrup. Yoghurts supplemented with dates had high WHC and less syneresis values. Further, with increasing level of supplementation, the former values increased and the later decreased. This probably, could be attributed to the increasing of yoghurt total solids by adding dates. Nouri et al. (2011) noted that reduction in whey separation and increase in WHC of yoghurt was presented when the total solids were increased by adding fruits.
Values of viscosity, curd tension, WHC and syneresis of various yoghurt samples were affected significantly $(\mathrm{P}<0.05)$ by storage time. The viscosity, curd tension and WHC values increased during storage from the first day until the seventh day and after they decreased to the end of storage period. However, syneresis values lowered till the seventh day then increased. The results of present study are in relatively accordance with Aryana et al. (2006). They reported a decrease in viscosity of yoghurt with increase of storage of time.

\section{Changes in chemical composition of yoghurt during refrigerated storage for 15 days}

Data shown in Table 4 illustrate the effect of using ABT culture and supplementation of yoghurt with 10 and $15 \%$ rutub dates on the titratable acidity (\% lactic acid), $\mathrm{pH}$, redox potential $\left(\mathrm{E}_{\mathrm{h}}\right)$, carbohydrate and total solids (TS) contents during the refrigerated storage. Using of ABT starter (treatment B) decreased titratable acidity and $\mathrm{E}_{\mathrm{h}}$ and increased $\mathrm{pH}$ and carbohydrate values of fresh yoghurt and during storage period as compared with that made by classic culture (treatment A). TS contents were similar in either yoghurt samples prepared by classic or ABT starters. These results agreed with Shihata and Shah (2002) and disagreed with Kehagias et al. (2006). Shihata and Shah (2002) reported that the $\mathrm{ABT}$ cultures are known to produce yoghurt with a fine, mild taste and low post acidification whereas Kehagias et al. (2006) stated that the addition of bifidobacteria to yoghurt starter increased acidity of yoghurt which attributed to the formation of both acetic and lactic acids by B. bifidum. In bioyoghurt special attention should be given to avoid over acidification since this could affect the stability of bifidobacteria during storage.

On the other hand, addition of dates to milk increased titratable acidity and decreased $\mathrm{pH}$ values of yoghurt which could be attributed to date compounds (Table 4). Moreover, the rise in titratable acidity or drop in $\mathrm{pH}$ in fortified yoghurt was more than that observed in the control. This refers to the activation of added dates to yoghurt microorganisms during storage. Al-Otaibi and ElDemerdash (2013) stated that acidity values of fermented camel milk fortified with $1,2.5$ and $5 \%$ of date depis were higher than that of control. Fortunately, data of yoghurt $\mathrm{E}_{\mathrm{h}}$ on day 1 and during storage period for treatments supplemented with rutub dates were lower than those of control which may enhanced the viability of yoghurt and ABT cultures. These findings are in agreement with the findings of Vasiljevic and Shah (2008) who reported that the lower $\mathrm{E}_{\mathrm{h}}$ of yoghurt may improve the viability of $S$. thermophilus, L. bulgaricus, L. acidophilus and $B$. animalis.

Table 2 Effect of using of ABT culture and adding of rutub dates to cow's milk on yoghurt rheological properties (means \pm SD)*

\begin{tabular}{|c|c|c|c|c|c|}
\hline \multirow[t]{2}{*}{ Properties } & \multirow[t]{2}{*}{ Treatments } & \multicolumn{3}{|c|}{ Storage period (day) } & \multirow[t]{2}{*}{ Means \pm SD } \\
\hline & & 1 & 7 & 15 & \\
\hline \multirow{7}{*}{$\begin{array}{l}\text { Coagulation time } \\
\qquad(\min )\end{array}$} & $\mathrm{A}$ & 180 & - & - & $180 \pm 7.07^{b}$ \\
\hline & $\mathrm{B}$ & 150 & - & - & $150 \pm 7.07^{\mathrm{d}}$ \\
\hline & $\mathrm{C}$ & 140 & - & - & $140 \pm 7.07^{\mathrm{d}}$ \\
\hline & $\mathrm{D}$ & 210 & - & - & $210 \pm 7.07^{\mathrm{a}}$ \\
\hline & $\mathrm{E}$ & 175 & - & - & $175 \pm 7.07^{\mathrm{bc}}$ \\
\hline & $\mathrm{F}$ & 155 & - & - & $155 \pm 7.07^{\mathrm{cd}}$ \\
\hline & Means \pm SD & & - & - & \\
\hline \multirow{7}{*}{$\begin{array}{l}\text { Viscosity } \\
\text { (CP) }\end{array}$} & $\mathrm{A}$ & 1230 & 1245 & 741 & $1072 \pm 256.6^{\mathrm{d}}$ \\
\hline & $\mathrm{B}$ & 1305 & 1326 & 821 & $1150 \pm 255.5^{\mathrm{c}}$ \\
\hline & $\mathrm{C}$ & 1443 & 1468 & 894 & $1268 \pm 290.2^{\mathrm{a}}$ \\
\hline & $\mathrm{D}$ & 1102 & 1130 & 685 & $972 \pm 222.9^{\mathrm{e}}$ \\
\hline & $\mathrm{E}$ & 1222 & 1241 & 756 & $1073 \pm 245.7^{\mathrm{d}}$ \\
\hline & $\mathrm{F}$ & 1347 & 1377 & 802 & $1175 \pm 289.5^{\mathrm{b}}$ \\
\hline & Means \pm SD & $1274 \pm 112.2^{\mathrm{B}}$ & $1297 \pm 113.1^{\mathrm{A}}$ & $783 \pm 69.1^{\mathrm{C}}$ & \\
\hline \multirow{7}{*}{ Curd tension (gm) } & $\mathrm{A}$ & 30.29 & 32.11 & 31.05 & $31.15 \pm 1.37^{\mathrm{c}}$ \\
\hline & $\mathrm{B}$ & 33.65 & 34.87 & 33.98 & $34.17 \pm 1.23^{\mathrm{b}}$ \\
\hline & $\mathrm{C}$ & 35.24 & 37.11 & 36.09 & $36.15 \pm 1.38^{\mathrm{a}}$ \\
\hline & $\mathrm{D}$ & 28.65 & 29.88 & 29.12 & $29.22 \pm 1.22^{\mathrm{d}}$ \\
\hline & $\mathrm{E}$ & 30.35 & 32.23 & 31.37 & $31.32 \pm 1.38^{\mathrm{c}}$ \\
\hline & $\mathrm{F}$ & 31.28 & 33.96 & 32.14 & $32.79 \pm 1.42^{\mathrm{bc}}$ \\
\hline & Means \pm SD & $31.74 \pm 2.55^{\mathrm{B}}$ & $33.36 \pm 2.62^{\mathrm{A}}$ & $32.29 \pm 2.55^{\mathrm{AB}}$ & \\
\hline \multirow{7}{*}{$\begin{array}{l}\text { Water holding } \\
\text { capacity }(\%)\end{array}$} & $\mathrm{A}$ & 91.22 & 93.35 & 92.44 & $92.34 \pm 1.45^{\mathrm{c}}$ \\
\hline & B & 94.54 & 97.62 & 96.14 & $96.10 \pm 1.76^{\mathrm{a}}$ \\
\hline & $\mathrm{C}$ & 96.07 & 98.77 & 97.23 & $97.36 \pm 1.63^{\mathrm{a}}$ \\
\hline & $\mathrm{D}$ & 89.90 & 92.83 & 90.91 & $91.21 \pm 1.72^{\mathrm{c}}$ \\
\hline & $\mathrm{E}$ & 93.11 & 95.59 & 94.36 & $94.35 \pm 1.56^{\mathrm{b}}$ \\
\hline & $\mathrm{F}$ & 95.07 & 97.52 & 96.31 & $96.30 \pm 1.55^{\mathrm{a}}$ \\
\hline & Means \pm SD & $93.3 \pm 2.49^{C}$ & $95.95 \pm 2.55^{\mathrm{A}}$ & $94.56 \pm 2.58^{\mathrm{B}}$ & \\
\hline
\end{tabular}


Table 3 Effect of using of ABT culture and adding of rutub dates to cow's milk on yoghurt syneresis* (means \pm SD)

\begin{tabular}{|c|c|c|c|c|c|}
\hline \multirow[t]{2}{*}{ Treatments } & \multirow{2}{*}{$\begin{array}{c}\text { Time of syneresis } \\
(\mathrm{min})\end{array}$} & \multicolumn{3}{|c|}{ Storage period (day) } & \multirow[t]{2}{*}{ Means \pm SD } \\
\hline & & 1 & 7 & 15 & \\
\hline \multirow{5}{*}{ A } & 10 & 1.16 & 0.94 & 1.11 & $1.07 \pm 0.104$ \\
\hline & 30 & 2.58 & 1.89 & 2.21 & $2.23 \pm 0.309$ \\
\hline & 60 & 3.85 & 2.93 & 3.25 & $3.34 \pm 0.418$ \\
\hline & 120 & 4.94 & 3.84 & 4.95 & $4.58 \pm 0.571$ \\
\hline & Means \pm SD & $3.13 \pm 1.510^{\mathrm{A}}$ & $2.40 \pm 1.164^{\mathrm{C}}$ & $2.88 \pm 1.51^{\mathrm{B}}$ & $2.804 \pm 1.38^{\mathrm{b}}$ \\
\hline \multirow{5}{*}{ B } & 10 & 0.57 & 0.32 & 0.44 & $0.44 \pm 0.112$ \\
\hline & 30 & 1.19 & 0.63 & 0.85 & $0.89 \pm 0.253$ \\
\hline & 60 & 1.78 & 0.96 & 1.29 & $1.34 \pm 0.369$ \\
\hline & 120 & 2.28 & 1.24 & 1.93 & $1.33 \pm 0.989$ \\
\hline & Means \pm SD & $1.45 \pm 0.684^{\mathrm{A}}$ & $0.64 \pm 0.380^{\mathrm{C}}$ & $0.91 \pm 0.567^{\mathrm{B}}$ & $1.003 \pm 0.63^{\mathrm{e}}$ \\
\hline \multirow{5}{*}{$\mathrm{C}$} & 10 & 0.42 & 0.22 & 0.39 & $0.34 \pm 0.096$ \\
\hline & 30 & 0.97 & 0.54 & 0.66 & $0.72 \pm 0.199$ \\
\hline & 60 & 1.36 & 0.81 & 1.07 & $1.08 \pm 0.246$ \\
\hline & 120 & 1.76 & 1.09 & 1.68 & $1.51 \pm 0.328$ \\
\hline & Means \pm SD & $1.13 \pm 0.529^{\mathrm{A}}$ & $0.67 \pm 0.343^{\mathrm{C}}$ & $0.95 \pm 0.518^{\mathrm{B}}$ & $0.915 \pm 0.49^{\mathrm{e}}$ \\
\hline \multirow{5}{*}{$\mathrm{D}$} & 10 & 1.66 & 1.09 & 1.35 & $1.36 \pm 0.256$ \\
\hline & 30 & 2.98 & 1.96 & 2.47 & $2.47 \pm 0.457$ \\
\hline & 60 & 4.26 & 3.24 & 3.56 & $3.69 \pm 0.470$ \\
\hline & 120 & 5.77 & 4.26 & 5.68 & $5.24 \pm 0.758$ \\
\hline & Means \pm SD & $3.67 \pm 1.628^{A}$ & $2.64 \pm 1.293^{\mathrm{B}}$ & $3.26 \pm 1.708^{\mathrm{AB}}$ & $3.190 \pm 1.55^{\mathrm{a}}$ \\
\hline \multirow{5}{*}{ E } & 10 & 0.91 & 0.52 & 0.67 & $0.70 \pm 0.177$ \\
\hline & 30 & 1.97 & 0.93 & 1.34 & $1.41 \pm 0.469$ \\
\hline & 60 & 2.90 & 1.17 & 1.59 & $1.89 \pm 0.807$ \\
\hline & 120 & 3.54 & 1.67 & 2.47 & $2.56 \pm 0.839$ \\
\hline & Means \pm SD & $2.33 \pm 1.060^{A}$ & $1.72 \pm 0.445^{\mathrm{B}}$ & $1.52 \pm 0.689^{\mathrm{C}}$ & $1.64 \pm 0.9^{\mathrm{c}}$ \\
\hline \multirow{5}{*}{$\mathrm{F}$} & 10 & 0.58 & 0.32 & 0.54 & $0.48 \pm 0.126$ \\
\hline & 30 & 1.11 & 0.74 & 1.04 & $0.96 \pm 0.176$ \\
\hline & 60 & 1.63 & 1.07 & 1.35 & $1.35 \pm 0.251$ \\
\hline & 120 & 1.99 & 1.27 & 2.05 & $1.77 \pm 0.389$ \\
\hline & Means \pm SD & $1.33 \pm 0.570^{\mathrm{A}}$ & $0.85 \pm 0.385^{\mathrm{B}}$ & $1.24 \pm 0.585^{\mathrm{A}}$ & $1.141 \pm 0.54^{\mathrm{d}}$ \\
\hline
\end{tabular}

As it is expected, fortification of milk with various concentrations of dates increased carbohydrate and TS contents of the resulted yoghurt. These results are similar to those obtained by Kale et al., (2011). They found that supplementation of yoghurt with different levels of date palm past decreased moisture and increased total solids, fat and protein contents.

Overall, during storage titratable acidity values of all treatments and control increased due to the activity of the starter culture. Redox potential and TS had the same trend. Morris (2000) reported that $E_{h}$ of a growth medium has an inverse relationship with $\mathrm{pH}$. Therefore, this increase in yoghurt $\mathrm{E}_{\mathrm{h}}$ from day 1 to 15 could be attributed to the decrease in $\mathrm{pH}$ over the same storage period and/or increase in oxygen tension due to air permeability through the plastic containers during storage. On the contrary of acidity, $\mathrm{E}_{\mathrm{h}}$ and $\mathrm{TS}, \mathrm{pH}$ and carbohydrate values significantly reduced in all treatments during storage. This decrease was due to their fermentation by starter cultures.

The changes in fat, dietary fiber, ash and mineral contents during the refrigerated storage of yoghurt are presented in Table 5. No significant differences in values of fat, ash and minerals between yoghurts made using classic or ABT cultures at zero time or within storage stage.

Table 4 Effect of using ABT culture and adding of rutub dates to cow's milk on some physico-chemical properties of yoghurt (means $\pm \mathrm{SD})$

\begin{tabular}{|c|c|c|c|c|c|}
\hline \multirow[t]{2}{*}{ Properties } & \multirow[t]{2}{*}{ Treatments } & \multicolumn{3}{|c|}{ Storage period (day) } & \multirow[t]{2}{*}{ Means \pm SD } \\
\hline & & 1 & 7 & 15 & \\
\hline \multirow{7}{*}{$\begin{array}{c}\text { Acidity } \\
\%\end{array}$} & $\mathrm{~A}$ & 0.72 & 1.01 & 1.17 & $0.97 \pm 0.205^{\mathrm{d}}$ \\
\hline & B & 0.77 & 1.14 & 1.33 & $1.08 \pm 0.256^{\mathrm{b}}$ \\
\hline & $\mathrm{C}$ & 0.85 & 1.25 & 1.48 & $1.19 \pm 0.285^{\mathrm{a}}$ \\
\hline & $\mathrm{D}$ & 0.59 & 0.82 & 1.00 & $0.80 \pm 0.184^{\mathrm{f}}$ \\
\hline & $\mathrm{E}$ & 0.66 & 0.95 & 1.12 & $0.91 \pm 0.209^{\mathrm{e}}$ \\
\hline & $\mathrm{F}$ & 0.74 & 1.08 & 1.30 & $1.04 \pm 0.253^{\mathrm{c}}$ \\
\hline & Means \pm SD & $0.72 \pm 0.087^{\mathrm{C}}$ & $1.04 \pm 0.145^{\mathrm{B}}$ & $1.23 \pm 0.164^{\mathrm{A}}$ & \\
\hline \multirow{7}{*}{$\begin{array}{c}\mathrm{pH} \\
\text { values }\end{array}$} & A & 4.78 & 4.54 & 4.38 & $4.57 \pm 0.181^{\mathrm{c}}$ \\
\hline & $\mathrm{B}$ & 4.69 & 4.45 & 4.30 & $4.48 \pm 0.176^{\mathrm{e}}$ \\
\hline & $\mathrm{C}$ & 4.59 & 4.32 & 4.18 & $4.36 \pm 0.187^{\mathrm{f}}$ \\
\hline & $\mathrm{D}$ & 4.91 & 4.65 & 4.55 & $4.70 \pm 0.166^{\mathrm{a}}$ \\
\hline & $\mathrm{E}$ & 4.80 & 4.56 & 4.46 & $4.61 \pm 0.157^{b}$ \\
\hline & $\mathrm{F}$ & 4.74 & 4.50 & 4.35 & $4.53 \pm 0.178^{\mathrm{d}}$ \\
\hline & Means \pm SD & $4.75 \pm 0.104^{\mathrm{A}}$ & $4.50 \pm 0.107^{\mathrm{B}}$ & $4.37 \pm 0.123^{\mathrm{C}}$ & \\
\hline \multirow{7}{*}{$\begin{array}{l}\mathrm{Eh} \\
\mathrm{mV}\end{array}$} & $\mathrm{A}$ & 125.1 & 137.8 & 169.0 & $143 \pm 20.25^{\mathrm{a}}$ \\
\hline & B & 120.2 & 131.4 & 162.1 & $138 \pm 19.50^{\mathrm{b}}$ \\
\hline & $\mathrm{C}$ & 114.6 & 126.9 & 158.4 & $133 \pm 20.26^{\mathrm{c}}$ \\
\hline & D & 116.3 & 129.2 & 165.0 & $136 \pm 22.77^{b}$ \\
\hline & $\mathrm{E}$ & 109.5 & 121.7 & 159.2 & $130 \pm 23.21^{\mathrm{d}}$ \\
\hline & $\mathrm{F}$ & 100.6 & 115.6 & 153.5 & $123 \pm 24.46^{\mathrm{e}}$ \\
\hline & Means \pm SD & $114.4 \pm 8.34^{\mathrm{C}}$ & $127.1 \pm 7.60^{\mathrm{A}}$ & $161.2 \pm 5.64^{\mathrm{B}}$ & \\
\hline \multirow{7}{*}{$\begin{array}{c}\text { Carbohydrate } \\
\%\end{array}$} & A & 3.51 & 3.35 & 3.21 & $3.36 \pm 0.173^{\mathrm{e}}$ \\
\hline & B & 8.46 & 8.25 & 8.10 & $8.27 \pm 0.195^{\mathrm{d}}$ \\
\hline & $\mathrm{C}$ & 10.98 & 10.67 & 10.45 & $10.62 \pm 0.33^{b}$ \\
\hline & $\mathrm{D}$ & 3.86 & 3.76 & 3.69 & $3.77 \pm 0.084^{\mathrm{e}}$ \\
\hline & $\mathrm{E}$ & 8.87 & 8.71 & 8.60 & $8.73 \pm 0.151^{\mathrm{c}}$ \\
\hline & $\mathrm{F}$ & 11.39 & 11.18 & 11.01 & $11.19 \pm 0.67^{\mathrm{a}}$ \\
\hline & Means \pm SD & $7.84 \pm 3.29^{\mathrm{A}}$ & $7.61 \pm 3.18^{\mathrm{AB}}$ & $7.51 \pm 3.178^{\mathrm{B}}$ & \\
\hline
\end{tabular}




\begin{tabular}{cccccc}
\hline & A & 13.84 & 13.99 & 14.08 & $13.97 \pm 0.14^{\mathrm{c}}$ \\
& $\mathrm{B}$ & 19.28 & 19.44 & 19.62 & $19.44 \pm 0.30^{\mathrm{b}}$ \\
$\mathrm{C}$ & 22.55 & 22.74 & 22.97 & $22.75 \pm 0.91^{\mathrm{a}}$ \\
$\mathrm{TS}$ & $\mathrm{D}$ & 13.51 & 13.77 & 13.94 & $13.74 \pm 0.38^{\mathrm{c}}$ \\
$\%$ & $\mathrm{E}$ & 19.17 & 19.34 & 19.52 & $19.34 \pm 0.72^{\mathrm{b}}$ \\
& $\mathrm{F}$ & 22.37 & 22.64 & 22.88 & $22.63 \pm 0.67^{\mathrm{a}}$ \\
\cline { 2 - 6 } & Means \pm SD & $18.45 \pm 3.87^{\mathrm{A}}$ & $18.65 \pm 3.83^{\mathrm{A}}$ & $18.83 \pm 3.84^{\mathrm{A}}$ \\
\hline${ }^{\text {abcde }}$ Letters indicate significant differences between Labneh treatments & & &
\end{tabular}

Fortification of yoghurt with various concentrations of date had no clear effect on fat contents. Because of milk and dairy products do not contain fiber so the dietary fiber content of yoghurt was very little $(\sim 0.42 \%)$ even after incorporation of date. However date addition significantly increased ash, $\mathrm{K}, \mathrm{Ca}, \mathrm{P}, \mathrm{Mg}, \mathrm{Na}$ and Fe values and the increasing rates were more noticeable in potassium content These results concur with those of Gad $\boldsymbol{e t}$ al., (2010) who stated that the $\mathrm{HCl}$ soluble mineral content ( $\mathrm{K}, \mathrm{Ca}, \mathrm{P}, \mathrm{Mg}, \mathrm{Fe}$ and $\mathrm{Zn}$ ) in yoghurt made using skim milk and $10 \%$ date juice was higher than that of plain yoghurt. Generally, increasing of acidity and mineral content of yoghurt as a result of fortification with date raises the healthy benefits. The acidity of yoghurt is thought to increase the absorption of certain minerals including calcium, phosphorous and magnesium compared with other dairy products and may reduce the inhibitory effect of some compounds such as phytic acid which is known to interfere with mineral absorption (particularly calcium). Yoghurt is also good source of phosphorus which serves many functions in the body and is necessary for healthy bones and teeth as well as energy production, cell membrane structure, tissue growth and regulation of $\mathrm{pH}$ levels in the body. Magnesium, potassium, zinc, selenium, iron, iodine and chloride are also found in yoghurt (The Dairy Council 2007).
Also, Table 5 shows that mineral content except iron increased with the progressive of storage period in all yoghurt samples. We have no explanation for iron reducing other than to attribute it to microorganisms' activity in yoghurt Tammam et al., (2013) reported that $\mathrm{K}, \mathrm{Ca}, \mathrm{P}, \mathrm{Mg}$ and $\mathrm{Fe}$ contents of yoghurt supplemented with $1,3,5$ and $7 \%$ date syrup (dibis) increased with the advancing of storage period

As evident from Table 6 both types of yoghurt manufactured by classic and ABT cultures possessed nearly the same TN contents. However, WSN, total phenols and TVFA contents were higher in the former than those of the later. Increasing of WSN values in classic yoghurt may be due to proteolytic activity (endopeptidase) of L. delbrueckii subsp. bulgaricus which hydrolyzed casein to polypeptides then; the later was hydrolyzed to amino acids with exopeptidases produced by $S$. thermophilus (Tamime and Robinson, 1999). Fortification of yoghurt with 10 and $15 \%$ date increased TN, WSN total phenols and TVFA contents which may refer to the stimulation effect of date components on yoghurt microorganisms. On the other side, rising of total phenols content of yoghurt by adding date increases antioxidant activity. Mansouri et al., (2005) reported that the predominant phenolics found in date fruits are very active as antioxidants.

Table 5 Effect of using ABT culture and adding of rutub dates to cow's milk on chemical composition of yoghurt (means \pm SD)

\begin{tabular}{|c|c|c|c|c|c|}
\hline \multirow[t]{2}{*}{ Properties } & \multirow[t]{2}{*}{ Treatments } & \multicolumn{3}{|c|}{ Storage period (day) } & \multirow[t]{2}{*}{ Means \pm SD } \\
\hline & & 1 & 7 & 15 & \\
\hline \multirow{7}{*}{$\begin{array}{c}\text { Fat } \\
\%\end{array}$} & $\mathrm{~A}$ & 4.8 & 4.9 & 4.9 & $4.87 \pm 0.121^{\mathrm{a}}$ \\
\hline & B & 4.8 & 4.8 & 4.9 & $4.83 \pm 0.197^{\mathrm{a}}$ \\
\hline & $\mathrm{C}$ & 4.7 & 4.8 & 4.8 & $4.77 \pm 0.197^{\mathrm{a}}$ \\
\hline & $\mathrm{D}$ & 4.7 & 4.9 & 4.9 & $4.83 \pm 0.186^{\mathrm{a}}$ \\
\hline & $\mathrm{E}$ & 4.9 & 4.8 & 4.9 & $4.86 \pm 0.163^{\mathrm{a}}$ \\
\hline & $\mathrm{F}$ & 4.8 & 4.9 & 4.9 & $4.87 \pm 0.225^{\mathrm{a}}$ \\
\hline & Means \pm SD & $4.8 \pm 0.195^{\mathrm{A}}$ & $4.8 \pm 0.157^{\mathrm{A}}$ & $4.88 \pm 0.170^{\mathrm{A}}$ & \\
\hline \multirow{7}{*}{$\begin{array}{c}\text { Dietary } \\
\text { Fiber } \\
\%\end{array}$} & A & - & - & - & - \\
\hline & B & 0.34 & 0.34 & 0.35 & $0.34 \pm 0.012^{\mathrm{c}}$ \\
\hline & $\mathrm{C}$ & 0.45 & 0.46 & 0.48 & $0.46 \pm 0.023^{\mathrm{a}}$ \\
\hline & $\mathrm{D}$ & - & - & - & - \\
\hline & $\mathrm{E}$ & 0.36 & 0.37 & 0.37 & $0.37 \pm 0.016^{\mathrm{d}}$ \\
\hline & $\mathrm{F}$ & 0.44 & 0.47 & 0.49 & $0.47 \pm 0.029^{\mathrm{b}}$ \\
\hline & Means \pm SD & $0.26 \pm 0.200^{\mathrm{B}}$ & $0.27 \pm 0.207^{\mathrm{AB}}$ & $0.28 \pm 0.215^{\mathrm{A}}$ & \\
\hline \multirow{7}{*}{$\begin{array}{c}\text { Ash } \\
\%\end{array}$} & A & 0.86 & 0.91 & 0.94 & $0.90 \pm 0.041^{\mathrm{c}}$ \\
\hline & $\mathrm{B}$ & 0.92 & 0.96 & 0.99 & $0.96 \pm 0.035^{b}$ \\
\hline & $\mathrm{C}$ & 0.98 & 1.05 & 1.08 & $1.037 \pm 0.050^{\mathrm{a}}$ \\
\hline & $\mathrm{D}$ & 0.88 & 0.90 & 0.93 & $0.90 \pm 0.029^{c}$ \\
\hline & $\mathrm{E}$ & 0.94 & 0.97 & 0.98 & $0.96 \pm 0.026^{\mathrm{b}}$ \\
\hline & $\mathrm{F}$ & 1.00 & 1.04 & 1.07 & $1.03 \pm 0.039^{\mathrm{a}}$ \\
\hline & Means \pm SD & $0.93 \pm 0.055^{\mathrm{C}}$ & $0.97 \pm 0.063^{\mathrm{B}}$ & $0.99 \pm 0.063^{\mathrm{A}}$ & \\
\hline \multirow{7}{*}{$\begin{array}{c}\mathrm{K} \\
(\mathrm{mg} / \mathrm{g})\end{array}$} & $\mathrm{A}$ & 1.43 & 1.47 & 1.49 & $1.46 \pm 0.033^{\mathrm{c}}$ \\
\hline & B & 2.11 & 2.15 & 2.24 & $2.17 \pm 0.066^{\mathrm{b}}$ \\
\hline & $\mathrm{C}$ & 2.91 & 2.95 & 3.01 & $2.95 \pm 0.048^{\mathrm{a}}$ \\
\hline & $\mathrm{D}$ & 1.44 & 1.46 & 1.48 & $1.46 \pm 0.029^{c}$ \\
\hline & $\mathrm{E}$ & 2.13 & 2.15 & 2.22 & $2.17 \pm 0.099^{\mathrm{b}}$ \\
\hline & $\mathrm{F}$ & 2.95 & 2.97 & 3.02 & $2.98 \pm 0.037^{\mathrm{a}}$ \\
\hline & Means \pm SD & $2.16 \pm 0.638^{\mathrm{B}}$ & $2.19 \pm 0.640^{\mathrm{B}}$ & $2.24 \pm 0.653^{\mathrm{A}}$ & \\
\hline \multirow{7}{*}{$\begin{array}{c}\mathrm{Ca} \\
(\mathrm{mg} / \mathrm{g})\end{array}$} & $\mathrm{A}$ & 1.15 & 1.17 & 1.20 & $1.17 \pm 0.031^{\mathrm{d}}$ \\
\hline & B & 1.49 & 1.52 & 1.53 & $1.51 \pm 0.026^{\mathrm{c}}$ \\
\hline & $\mathrm{C}$ & 1.85 & 1.89 & 1.92 & $1.89 \pm 0.037^{\mathrm{a}}$ \\
\hline & $\mathrm{D}$ & 1.17 & 1.18 & 1.22 & $1.19 \pm 0.032^{\mathrm{d}}$ \\
\hline & $\mathrm{E}$ & 1.52 & 1.56 & 1.56 & $1.54 \pm 0.032^{\mathrm{b}}$ \\
\hline & $\mathrm{F}$ & 1.83 & 1.86 & 1.90 & $1.86 \pm 0.039^{\mathrm{a}}$ \\
\hline & Means \pm SD & $1.50 \pm 0.291^{\mathrm{C}}$ & $1.53 \pm 0.299^{\mathrm{B}}$ & $1.55 \pm 0.299^{\mathrm{A}}$ & \\
\hline \multirow{7}{*}{$\begin{array}{c}\mathrm{P} \\
(\mathrm{mg} / \mathrm{g})\end{array}$} & $\mathrm{A}$ & 0.95 & 0.98 & 1.04 & $0.99 \pm 0.042^{\mathrm{c}}$ \\
\hline & B & 1.21 & 1.22 & 1.27 & $1.23 \pm 0.034^{\mathrm{b}}$ \\
\hline & $\mathrm{C}$ & 1.48 & 1.50 & 1.53 & $1.50 \pm 0.032^{\mathrm{a}}$ \\
\hline & $\mathrm{D}$ & 0.97 & 1.00 & 1.02 & $0.99 \pm 0.027^{\mathrm{c}}$ \\
\hline & $\mathrm{E}$ & 1.19 & 1.23 & 1.25 & $1.22 \pm 0.038^{\mathrm{b}}$ \\
\hline & $\mathrm{F}$ & 1.48 & 1.53 & 1.54 & $1.51 \pm 0.031^{\mathrm{a}}$ \\
\hline & Means \pm SD & $1.213 \pm 0.223^{\mathrm{C}}$ & $1.24 \pm 0.225^{\mathrm{B}}$ & $1.27 \pm 0.217^{\mathrm{A}}$ & \\
\hline \multirow{5}{*}{$\begin{array}{c}\mathrm{Mg} \\
(\mathrm{mg} / \mathrm{g})\end{array}$} & $\mathrm{A}$ & 0.13 & 0.15 & 0.15 & $0.31 \pm 0.042^{\mathrm{bc}}$ \\
\hline & $\mathrm{B}$ & 0.37 & 0.40 & 0.41 & $0.39 \pm 0.026^{\mathrm{b}}$ \\
\hline & $\mathrm{C}$ & 0.70 & 0.77 & 0.80 & $0.76 \pm 0.050^{\mathrm{a}}$ \\
\hline & D & 0.14 & 0.14 & 0.16 & $0.14 \pm 0.026^{\mathrm{c}}$ \\
\hline & $\mathrm{E}$ & 0.36 & 0.39 & 0.43 & $0.39 \pm 0.039^{b}$ \\
\hline
\end{tabular}




\begin{tabular}{|c|c|c|c|c|c|}
\hline & $\mathrm{F}$ & 0.73 & 0.76 & 0.82 & $0.77 \pm 0.048^{\mathrm{a}}$ \\
\hline & Means \pm SD & $0.40 \pm 0.250^{\mathrm{A}}$ & $0.43 \pm 0.267^{\mathrm{A}}$ & $0.54 \pm 0.328^{\mathrm{A}}$ & \\
\hline \multirow{7}{*}{$\begin{array}{c}\mathrm{Na} \\
(\mathrm{mg} / \mathrm{g})\end{array}$} & $\mathrm{A}$ & 0.52 & 0.56 & 0.58 & $0.55 \pm 0.035^{\mathrm{d}}$ \\
\hline & B & 0.61 & 0.62 & 0.65 & $0.63 \pm 0.026^{\mathrm{c}}$ \\
\hline & $\mathrm{C}$ & 0.66 & 0.68 & 0.69 & $0.68 \pm 0.020^{\mathrm{a}}$ \\
\hline & $\mathrm{D}$ & 0.50 & 0.54 & 0.56 & $0.53 \pm 0.031^{\mathrm{d}}$ \\
\hline & $\mathrm{E}$ & 0.62 & 0.64 & 0.64 & $0.63 \pm 0.024^{\mathrm{bc}}$ \\
\hline & $\mathrm{F}$ & 0.65 & 0.66 & 0.67 & $0.66 \pm 0.017^{\mathrm{ab}}$ \\
\hline & Means \pm SD & $0.59 \pm 0.067^{\mathrm{B}}$ & $0.61 \pm 0.056^{\mathrm{A}}$ & $0.63 \pm 0.051^{\mathrm{A}}$ & \\
\hline \multirow{7}{*}{$\begin{array}{c}\mathrm{Fe} \\
(\mathrm{ppm})\end{array}$} & $\mathrm{A}$ & 3.75 & 3.59 & 3.51 & $3.62 \pm 0.154^{\mathrm{c}}$ \\
\hline & B & 4.01 & 3.89 & 3.74 & $3.88 \pm 0.124^{b}$ \\
\hline & $\mathrm{C}$ & 4.32 & 4.14 & 4.01 & $4.16 \pm 0.153^{\mathrm{a}}$ \\
\hline & $\mathrm{D}$ & 3.77 & 3.57 & 3.49 & $3.61 \pm 0.130^{\mathrm{c}}$ \\
\hline & E & 4.04 & 3.90 & 3.76 & $3.90 \pm 0.128^{b}$ \\
\hline & $\mathrm{F}$ & 4.30 & 4.10 & 3.99 & $4.13 \pm 0.155^{\mathrm{a}}$ \\
\hline & Means \pm SD & $4.03 \pm 0.240^{\mathrm{A}}$ & $3.86 \pm 0.243^{\mathrm{B}}$ & $3.75 \pm 0.218^{C}$ & \\
\hline
\end{tabular}

Table 6 Effect of using ABT culture and adding of rutub dates to cow's milk on TN, WSN, total phenols and TVFA contents of yoghurt (means $\pm \mathrm{SD}$ )

\begin{tabular}{|c|c|c|c|c|c|}
\hline \multirow[t]{2}{*}{ Properties } & \multirow[t]{2}{*}{ Treatments } & \multicolumn{3}{|c|}{ Storage period (day) } & \multirow[t]{2}{*}{ Means \pm SD } \\
\hline & & 1 & 7 & 15 & \\
\hline \multirow{7}{*}{$\begin{array}{c}\mathrm{TN} \\
\%\end{array}$} & $\mathrm{~A}$ & 0.584 & 0.597 & 0.611 & $0.597 \pm 0.090^{\mathrm{a}}$ \\
\hline & $\mathrm{B}$ & 0.605 & 0.616 & 0.624 & $0.615 \pm 0.074^{\mathrm{a}}$ \\
\hline & $\mathrm{C}$ & 0.709 & 0.719 & 0.733 & $0.720 \pm 0.064^{\mathrm{a}}$ \\
\hline & $\mathrm{D}$ & 0.587 & 0.595 & 0.613 & $0.598 \pm 0.014^{\mathrm{a}}$ \\
\hline & $\mathrm{E}$ & 0.601 & 0.617 & 0.622 & $0.613 \pm 0.010^{\mathrm{a}}$ \\
\hline & $\mathrm{F}$ & 0.712 & 0.712 & 0.731 & $0.721 \pm 0.011^{\mathrm{a}}$ \\
\hline & Means \pm SD & $0.633 \pm 0.084^{\mathrm{A}}$ & $0.634 \pm 0.082^{\mathrm{A}}$ & $0.656 \pm 0.058^{\mathrm{A}}$ & \\
\hline \multirow{7}{*}{$\begin{array}{c}\text { WSN } \\
\%\end{array}$} & $\mathrm{~A}$ & 0.184 & 0.211 & 0.224 & $0.206 \pm 0.020^{\mathrm{d}}$ \\
\hline & B & 0.197 & 0.224 & 0.239 & $0.220 \pm 0.019^{c}$ \\
\hline & $\mathrm{C}$ & 0.219 & 0.248 & 0.262 & $0.243 \pm 0.020^{\mathrm{a}}$ \\
\hline & $\mathrm{D}$ & 0.171 & 0.197 & 0.211 & $0.193 \pm 0.019^{\mathrm{e}}$ \\
\hline & $\mathrm{E}$ & 0.188 & 0.213 & 0.231 & $0.211 \pm 0.019^{d}$ \\
\hline & $\mathrm{F}$ & 0.208 & 0.237 & 0.251 & $0.232 \pm 0.200^{\mathrm{b}}$ \\
\hline & Means \pm SD & $0.194 \pm 0.017^{\mathrm{C}}$ & $0.223 \pm 0.018^{\mathrm{B}}$ & $0.236 \pm 0.018^{\mathrm{A}}$ & \\
\hline \multirow{7}{*}{$\begin{array}{c}\text { Total phenols } \\
\mathrm{mg} / 100 \mathrm{~g}\end{array}$} & $\mathrm{~A}$ & 21.31 & 19.74 & 18.48 & $19.84 \pm 1.68^{\mathrm{e}}$ \\
\hline & B & 26.11 & 24.02 & 23.14 & $24.42 \pm 1.37^{\mathrm{b}}$ \\
\hline & $\mathrm{C}$ & 29.07 & 26.89 & 24.91 & $26.95 \pm 1.86^{\mathrm{a}}$ \\
\hline & $\mathrm{D}$ & 19.88 & 17.96 & 16.53 & $18.12 \pm 1.50^{\mathrm{e}}$ \\
\hline & $\mathrm{E}$ & 23.97 & 22.01 & 21.23 & $22.40 \pm 1.26^{\mathrm{c}}$ \\
\hline & $\mathrm{F}$ & 26.31 & 23.86 & 22.41 & $24.19 \pm 1.77^{b}$ \\
\hline & Means \pm SD & $24.44 \pm 3.29^{C}$ & $22.41 \pm 3.10^{\mathrm{B}}$ & $21.11 \pm 2.99^{\mathrm{A}}$ & \\
\hline \multirow{7}{*}{ TVFA* } & $\mathrm{A}$ & 8.2 & 9.0 & 9.6 & $8.93 \pm 0.656^{\mathrm{a}}$ \\
\hline & B & 8.5 & 9.4 & 10.1 & $9.33 \pm 0.726^{\mathrm{a}}$ \\
\hline & $\mathrm{C}$ & 8.9 & 9.7 & 10.5 & $9.71 \pm 0.781^{\mathrm{a}}$ \\
\hline & D & 7.9 & 8.8 & 9.3 & $8.68 \pm 0.676^{a}$ \\
\hline & $\mathrm{E}$ & 8.2 & 9.2 & 10.0 & $8.97 \pm 0.958^{\mathrm{a}}$ \\
\hline & $\mathrm{F}$ & 8.5 & 9.6 & 10.2 & $9.43 \pm 0.802^{\mathrm{a}}$ \\
\hline & Means \pm SD & $8.37 \pm 0.37^{\mathrm{A}}$ & $9.20 \pm 0.53^{\mathrm{A}}$ & $9.21 \pm 2.52^{\mathrm{A}}$ & \\
\hline
\end{tabular}

abcde Letters indicate significant differences between Labneh treatments

${ }^{\mathrm{ABCD}}$ Letters indicate significant differences between storage times

* expressed as ml $0.1 \mathrm{NaOH} 100 \mathrm{~g}^{-1}$ cheese

\section{Changes in microbial counts of yoghurt during refrigerated storage for 15 days}

Data of Table 7 illustrates the total viable bacterial counts (TVBC) and the viable counts of lactic acid bacteria, bifidobacteria, moulds and yeasts of yoghurt made using classic or ABT-5 cultures and supplementation of various concentrations of rutub date. Coliform bacteria were not detected over the storage period in control and all yoghurt samples which confirm the hygienic conditions of the manufacture. On the other hand, no moulds and yeasts growth was observed in different fresh yoghurt treatments but they appeared on the seventh day and increased till the end of storage. As well, TVBC for all samples increased through refrigerated storage. Conversely, counts of lactic acid bacteria and bifidobacteria gradually lowered during storage of yoghurt. Loss of viability of bifidobacteria during storage was more pronounced than was that of lactic acid bacteria. Viability losing of probiotic bacteria in fermented milk was reported to be due to acid injury to the organisms (Shah, 2000).

It could be viewed form Table 7 that ABT yoghurt had slightly higher numbers of TVBC and lactic acid bacteria than those of control for fresh samples and during storage. However, the numbers of moulds and yeasts were lower in the former than that the latter which may be attributed to the antifungal effect of bifidobacteria (Ergnkaya et al., 2006).

Yoghurt samples supplemented with various concentrations of date had higher numbers of TVBC compared to that in control samples. These results are in accordance with those of Kale $\boldsymbol{e t}$ al., (2011). Also, the highest counts of lactic acid bacteria and bifidobacteria were in yoghurt supplemented with rutub date.
As the level of date supplementation increased to $15 \%$ level, the viability of these bacteria improved further. This may be refer to the starter culture is activated by adding date to yoghurt. In supplementary, Al-Otaibi and El-Demerdash (2013) reported that addition of date depis improved the viability and stability of starter culture during storage of fermented camel milk. As shown in Table 6, almost, the numbers of moulds \& yeasts were similar in yoghurt samples with and without adding date.

The viability of bifidobacteria in fermented dairy products is a cause for concern. However, reducing of bifidobacteria numbers during storage period, but the recommended level of $10^{6} \mathrm{cfu}_{\mathrm{g}}{ }^{-1}$ of bifidobacteria as a probiotic was exceeded for all treatments of bio-yoghurt and remained above $10^{6} \mathrm{cfu}^{-\mathrm{g}^{-1}}$ until the end of storage period. One of the possibilities of high stability of bifidobacteria at refrigerated storage in these samples could be the absence of $L b$. delbrueckii ssp. bulgaricus which is known to produce post acidification. Post acidification could have further inhibitory effect on the Streptococcus thermophilus counts. Similar results and recommendations were obtained by FAO/WHO (2001) and Akin $e t$ al. (2007).

\section{Changes in sensory evaluation of yoghurt during refrigerated storage for 15} days

Organoleptic properties evaluation is an important indictor of potential consumer preferences. The popularity of yoghurt as a food component depends mainly on its sensory characteristics and addition of different flavours to yoghurt has been found to increase options for consumers and helps in marketing yoghurt and 
retaining consumer interests (Routray and Mishra, 2011). Impact of culture type and incorporation of date on sensory quality of yoghurt is given in Table 8 . Generally, all the samples gave a good total impression, were medium sour and did not have any marked off-flavour during the storage period. None of the supplemented yoghurts were judged to be weak. Fresh treatments ranked the highest scores of color, appearance, body, texture and flavour. They were described as good flavour, rich taste, normal body and texture and good appearance. Unfortunately, with storage progressive the sensory evaluation degrees of various samples lowered. This may be attributed to the developed acidity and/or whey separation, which may impair the pleasant acid flavour of yoghurt (El-Sayed et al., 2013)

Table 7 Effect of using ABT culture and adding of rutub dates to cow's milk on some microbial groups of yoghurt (means \pm SD)

\begin{tabular}{|c|c|c|c|c|c|}
\hline \multirow[t]{2}{*}{ Properties } & \multirow[t]{2}{*}{ Treatments } & \multicolumn{3}{|c|}{ Storage period (day) } & \multirow[t]{2}{*}{ Means \pm SD } \\
\hline & & 1 & 7 & 15 & \\
\hline \multirow{7}{*}{$\begin{array}{l}\text { TVBC } \\
\left(\mathrm{x} 10^{5}\right)\end{array}$} & $\mathrm{A}$ & 27 & 81 & 196 & $101 \pm 77.32^{\mathrm{e}}$ \\
\hline & $\mathrm{B}$ & 39 & 97 & 216 & $117 \pm 80.85^{\mathrm{d}}$ \\
\hline & $\mathrm{C}$ & 58 & 119 & 243 & $140 \pm 84.40^{\mathrm{c}}$ \\
\hline & $\mathrm{D}$ & 38 & 94 & 224 & $118 \pm 85.44^{\mathrm{d}}$ \\
\hline & $\mathrm{E}$ & 56 & 125 & 261 & $147 \pm 93.36^{\mathrm{b}}$ \\
\hline & $\mathrm{F}$ & 74 & 143 & 288 & $168 \pm 97.78^{a}$ \\
\hline & Means \pm SD & $48.67 \pm 16.63^{C}$ & $109.83 \pm 22.29^{\mathrm{B}}$ & $238.00 \pm 31.94^{\mathrm{A}}$ & \\
\hline \multirow{7}{*}{$\begin{array}{c}\text { Lactic acid } \\
\text { bacteria } \\
\left(\mathrm{x} 10^{3}\right)\end{array}$} & $\mathrm{A}$ & 11 & 9 & 6 & $8.67 \pm 2.73^{d}$ \\
\hline & $\mathrm{B}$ & 23 & 20 & 16 & $19.67 \pm 3.83^{\mathrm{c}}$ \\
\hline & $\mathrm{C}$ & 38 & 33 & 27 & $32.67 \pm 5.39^{b}$ \\
\hline & $\mathrm{D}$ & 20 & 17 & 14 & $16.67 \pm 3.83^{\mathrm{c}}$ \\
\hline & $\mathrm{E}$ & 37 & 32 & 25 & $31.33 \pm 5.82^{b}$ \\
\hline & $\mathrm{F}$ & 61 & 55 & 47 & $54.33 \pm 7.17^{\mathrm{a}}$ \\
\hline & Means \pm SD & $31.67 \pm 16.98^{\mathrm{A}}$ & $27.67 \pm 15.73^{\mathrm{B}}$ & $22.33 \pm 13.83^{\mathrm{C}}$ & \\
\hline \multirow{7}{*}{$\begin{array}{l}\text { Bifido-bacteria } \\
\quad\left(\mathrm{x} 10^{5}\right)\end{array}$} & $\mathrm{A}$ & - & - & - & - \\
\hline & $\mathrm{B}$ & - & - & - & - \\
\hline & $\mathrm{C}$ & - & - & - & - \\
\hline & $\mathrm{D}$ & 19 & 17 & 13 & $16.33 \pm 2.94^{\mathrm{c}}$ \\
\hline & $\mathrm{E}$ & 27 & 22 & 17 & $22.00 \pm 4.98^{b}$ \\
\hline & $\mathrm{F}$ & 32 & 28 & 21 & $27.00 \pm 5.21^{\mathrm{a}}$ \\
\hline & Means \pm SD & $13.00 \pm 14.20^{\mathrm{A}}$ & $11.17 \pm 12.17^{\mathrm{B}}$ & $8.50 \pm 9.26^{\mathrm{C}}$ & \\
\hline \multirow{7}{*}{$\begin{array}{l}\text { Moulds \& Yeast } \\
\qquad\left(\mathrm{x} 10^{3}\right)\end{array}$} & $\mathrm{A}$ & 0 & 2 & 8 & $3.33 \pm 3.83^{\mathrm{ab}}$ \\
\hline & B & 0 & 3 & 8 & $4.33 \pm 4.68^{\mathrm{a}}$ \\
\hline & $\mathrm{C}$ & 0 & 3 & 9 & $4.67 \pm 5.16^{\mathrm{a}}$ \\
\hline & $\mathrm{D}$ & 0 & 1 & 5 & $2.00 \pm 2.45^{\mathrm{b}}$ \\
\hline & $\mathrm{E}$ & 0 & 3 & 5 & $3.67 \pm 3.72^{\mathrm{a}}$ \\
\hline & $\mathrm{F}$ & 0 & 2 & 7 & $3.67 \pm 4.32^{\mathrm{a}}$ \\
\hline & Means \pm SD & 0 & $2.33 \pm 1.23^{\mathrm{B}}$ & $8.50 \pm 2.24^{\mathrm{A}}$ & \\
\hline
\end{tabular}

${ }^{\text {abcde }}$ Letters indicate significant differences between Labneh treatment

${ }^{\mathrm{ABCD}}$ Letters indicate significant differences between storage times

Table 8 Effect of using ABT culture and adding of rutub dates to cow's milk on organoleptic properties of yoghurt (means \pm SD)

\begin{tabular}{|c|c|c|c|c|c|}
\hline \multirow[t]{2}{*}{ Properties } & \multirow[t]{2}{*}{ Treatments } & \multicolumn{3}{|c|}{ Storage period (day) } & \multirow[t]{2}{*}{ Means \pm SD } \\
\hline & & 1 & 7 & 15 & \\
\hline \multirow{7}{*}{$\begin{array}{c}\text { Color\& } \\
\text { Appearance } \\
\text { (15) }\end{array}$} & $\mathrm{A}$ & 14 & 14 & 13 & $13.67 \pm 1.21^{\mathrm{a}}$ \\
\hline & $\mathrm{B}$ & 13 & 13 & 13 & $13.00 \pm 1.09^{\mathrm{a}}$ \\
\hline & $\mathrm{C}$ & 13 & 13 & 12 & $12.67 \pm 1.21^{\mathrm{a}}$ \\
\hline & $\mathrm{D}$ & 14 & 14 & 13 & $13.67 \pm 1.21^{\mathrm{a}}$ \\
\hline & $\mathrm{E}$ & 13 & 13 & 12 & $12.67 \pm 1.21^{\mathrm{a}}$ \\
\hline & $\mathrm{F}$ & 13 & 13 & 12 & $12.67 \pm 1.21^{\mathrm{a}}$ \\
\hline & Means \pm SD & $13.33 \pm 1.15^{\mathrm{A}}$ & $13.33 \pm 1.15^{\mathrm{A}}$ & $12.50 \pm 1.17^{\mathrm{A}}$ & \\
\hline \multirow{7}{*}{$\begin{array}{c}\text { Body\& } \\
\text { Texture } \\
(35)\end{array}$} & $\mathrm{A}$ & 32 & 31 & 31 & $32.67 \pm 1.21^{\mathrm{a}}$ \\
\hline & B & 33 & 33 & 32 & $32.67 \pm 1.21^{\mathrm{a}}$ \\
\hline & $\mathrm{C}$ & 33 & 32 & 32 & $32.17 \pm 1.17^{\mathrm{ab}}$ \\
\hline & $\mathrm{D}$ & 31 & 31 & 30 & $30.67 \pm 1.21^{\mathrm{b}}$ \\
\hline & $\mathrm{E}$ & 32 & 31 & 31 & $31.00 \pm 1.09^{\mathrm{ab}}$ \\
\hline & $\mathrm{F}$ & 32 & 31 & 30 & $30.67 \pm 1.21^{\mathrm{b}}$ \\
\hline & Means \pm SD & $32.00 \pm 1.48^{\mathrm{A}}$ & $31.83 \pm 1.40^{\mathrm{A}}$ & $31.08 \pm 1.31^{\mathrm{A}}$ & \\
\hline \multirow{7}{*}{$\begin{array}{c}\text { Flavor } \\
(50)\end{array}$} & $\mathrm{A}$ & 45 & 45 & 43 & $44.33 \pm 1.50^{b}$ \\
\hline & $\mathrm{B}$ & 47 & 47 & 46 & $46.67 \pm 1.63^{\mathrm{a}}$ \\
\hline & $\mathrm{C}$ & 48 & 48 & 46 & $46.67 \pm 1.21^{\mathrm{a}}$ \\
\hline & $\mathrm{D}$ & 46 & 46 & 45 & $45.67 \pm 1.21^{\mathrm{ab}}$ \\
\hline & $\mathrm{E}$ & 48 & 47 & 47 & $47.33 \pm 1.21^{\mathrm{a}}$ \\
\hline & $\mathrm{F}$ & 48 & 48 & 47 & $47.67 \pm 1.21^{\mathrm{a}}$ \\
\hline & Means \pm SD & $46.83 \pm 1.70^{\mathrm{A}}$ & $46.67 \pm 1.43^{\mathrm{A}}$ & $45.67 \pm 1.77^{\mathrm{A}}$ & \\
\hline \multirow{7}{*}{$\begin{array}{l}\text { Total } \\
(100)\end{array}$} & $\mathrm{A}$ & 91 & 90 & 89 & $90.67 \pm 3.01^{\mathrm{a}}$ \\
\hline & B & 93 & 93 & 91 & $92.33 \pm 2.94^{\mathrm{a}}$ \\
\hline & $\mathrm{C}$ & 94 & 93 & 91 & $92.00 \pm 2.10^{\mathrm{a}}$ \\
\hline & $\mathrm{D}$ & 91 & 91 & 88 & $90.33 \pm 2.39^{\mathrm{a}}$ \\
\hline & $\mathrm{E}$ & 93 & 91 & 90 & $91.00 \pm 2.10^{\mathrm{a}}$ \\
\hline & $\mathrm{F}$ & 93 & 92 & 92 & $91.00 \pm 2.45^{\mathrm{a}}$ \\
\hline & Means \pm SD & $92.33 \pm 2.19^{\mathrm{A}}$ & $91.83 \pm 2.17^{\mathrm{A}}$ & $89.50 \pm 2.11^{\mathrm{B}}$ & \\
\hline
\end{tabular}

abcde Letters indicate significant differences between Labneh treatments

${ }^{\mathrm{ABCD}}$ Letters indicate significant differences between storage times

It was observed from Table 8 that organoleptic profiles of yoghurt made using of classic starter were found to be comparable to those of yoghurt samples manufactured by $\mathrm{ABT}$ culture at the beginning and during storage period.

Samples A and D (classic and ABT cultures respectively) gained approximately the same scores for color, appearance, body, texture and flavour. Abd El-Salam et al., (2011) cleared that the yoghurt sample made by addition of 
Bifidobacterium to yoghurt culture gained the highest scores for flavour, body\& texture and appearance among all the treatments.

Because of the sweet taste of date which is preferable for many consumers, it was not surprising that the flavour evaluation test of yoghurt supplemented with different date concentrations gained the highest scores. Addition of date not only improved yoghurt flavour but also body and texture. However, incorporation of date resulted in decrease in color and appearance scores. It could be concluded from color and appearance observation that consumers prefer light colored yoghurt whereas darkly colored yoghurt reduces acceptability. Gad et al., (2010) showed that panelists found the sensory attributes of yoghurt flavored with date palm syrup to be very acceptable. Yoghurt containing $10 \%$ date palm syrup had significantly higher sensory evaluation, higher taste rating, higher sweetness rating compared to plain yoghurt. The higher tasty and sweet was related to the date syrup that contain a high percentage of carbohydrate.

\section{CONCLUSIONS}

Yoghurt was produced using ABT-5 culture, supplemented with rutub date and evaluated for rheological, chemical, microbiological and sensory qualities. Addition of rutub date increased the total solids and mineral contents of the product thereby increasing its total food value. Bifidobacteria were greatly activated by mixing of rutub date with yoghurt milk which main that date could be utilized as sweeter and prebiotic in bio-yoghurt production. The result of the organoleptic properties of yoghurt cleared that incorporation of rutub date highly improved the sensory evaluation scores of the resulted yoghurt.

\section{REFERENCES}

ABD EL-SALAM, B.A., ZAYAN, A.F., MAILAM, M.A. 2011. Effect of fortification with honey and Bifidobacterium strain on the characteristics of yoghurt. Egyptian J. Dairy Sci., 39:65-74.

AKIN, M.B., AKIN, M.S., KIRMACI, Z. 2007. Effects of inulin and sugar levels on the viability of yoghurt and probiotic bacteria and the physical and sensory characteristics in probiotic ice-cream. Food Chem., 104:93 99. http://dx.doi.org/10.1016/j.foodchem.2006.11.030

AL-LAITH, A.A. 2007. Antioxidant activity of Bahraini date palm (Phoenix dactylifera L.) fruit of various cultivars. Int. J Food Sci. Technol., 43:10331040. http://dx.doi.org/10.1111/j.1365-2621.2007.01558.x

ALMEIDA, K.E., TAMIME, A.Y. OLIVEIRA, M.N. 2008. Acidification rates of probiotic bacteria in Minas frescal cheese whey. LWT - Food Sci. Technol. 41 311-316. http://dx.doi.org/10.1016/j.lwt.2007.02.021

AL-OTAIBI, EL-DEMERDASH. (2013). Nutritive value and characterization properties of fermented camel milk fortified with some date palm products chemical, bacteriological and sensory properties. International J Nutrition and Food Sci. 2:174-180. http://dx.doi.org/10.11648/i.ijnfs.20130204.13

ALVARO, E., ANDRIEUX, C., ROCHET, V., RIGOTTIER- GOIS, L., LEPERCQ, P., SUTREN, M., GALAN, P., DUVAL, Y., JUSTE, C., DOR, J. 2007. Composition and metabolism of the intestinal microbiota in consumers and non - consumers of yoghurt. British J. Nutrition. 97: 126 133. http://dx.doi.org/10.1017/s0007114507243065

AMERICAN PUBLIC HEALTH ASSOCIATION 1992. Standard methods for the examination of dairy products. Amer. Publ. Health Assoc. Inc. $12^{\text {th }}$ ed., New York, USA.

AOAC 2000. Association of Official Analytical Chemists. Official Methods of Analysis. $17^{\text {th }}$ ed, Washington, DC, USA.

AOAC 2005. Association of Official Analytical Chemists. Official Method of Analysis. $18^{\text {th }} \mathrm{ed}$, Washington, DC, USA.

ARYANA K.J., BARNES, H.T., EMMICK, T.K., MCGREW, P. MOSER, B. 2006. Lutein is stable in strawberry yoghurt and does not affect its characteristics. J Food Sci., 71: 467-472. http://dx.doi.org/10.1111/j.1750-3841.2006.00080.x

CHANDRASEKHARA, M.R., BHAGAWAN, R.K., SWAMINATHAN, M. SUBRAHMANYAN, V. 1957. The use of mammalian milk and processed milk foods in the feeding of infants. Indian J. Child. Health, 6:701-710.

COGAN, T.M., BERESFORD, T.P., STEELE, J., BROADBENT, J., SHAH, N.P., USTUNOL, Z. 2007. Advances in starter cultures and cultured food . $J$. Dairy Sci. 90 : 4005 - 4021. http://dx.doi.org/10.3168/jds.2006-765

DAMIN, M.R., MINOWA, E., ALCANTARA, M.R., OLIVEIRA, M.N. 2008 Effect of cold storage on culture viability and some rheological properties of fermented milk prepared with yoghurt and probiotic bacteria. J. Texture Studies, 39: 40-55. http://dx.doi.org/10.1111/j.1745-4603.2007.00129.x

DENIS, R. 2005.Technological aspects related to the use of bifidobacteria in dairy products. Lait (85) 39-56. http://dx.doi.org/10.1051/lait:2004026

DINAKAR, P., MISTRY, V.V. 1994. Growth and viability of Bifidobacterium bifidum in Cheddar cheese. J. Dairy Sci., 77:2854-2864. http://dx.doi.org/10.3168/jds.s0022-0302(94)77225-8

DUKE, J.A. 1992. Handbook of Phytochemical of GRAS Herbs and Other Economic Plants. CRC Press, Boca Raton, FL.

DUNCAN, D.B. 1955. Multiple Range and Multiple F-test. Biometrics, 11:1- 42. http://dx.doi.org/10.2307/3001478
ELlefSON, W., LILlA, Z., SUllivAN, D. 2005. Determination of "Net Carbohydrates" Using High-Performance Anion Exchange Chromatography. $J$ AOAC International, 88 (3): 714-719.

EL-SAYED, S.M., HAGRASS, A.E., ASKER, A.A., MALHAT, F.M., EL SAYED, M.M., ABD EL-SALAM, M.H. 2013. Effect of using some vitamin B producing microorganisms as adjunct cultures in the manufacture of yoghurt. Egyptian J. Dairy Sci., 41:127-136.

EL-SOHAIMY, S.A., HAFEZ, E.E. 2010. Biochemical and Nutritional Characterizations of Date Palm Fruits (Phoenix dactylifera L.). J. Applied Sciences Research, 6(8): 1060-1067.

ERGNKAYA, Z., KAVAS, C., VAR, I., KABAK, B., GUVEN, M. 2006 Antifungal activity of several lactic acid bacteria and bifidobacteria. (c.f. CAB abstracts, April, 2006).

FAO/WHO, 2001. Health and nutritional properties of probiotics in food including powder milk with live lactic acid bacteria. Report of a Joint FAO/WHO Expert Consultation on Evaluation of Health and Nutritional Properties of Probiotic in Food Including Powder milk with Live Lactic Acid Bacteria. Cordoba, Argentina. 1-4 October. ftp://ftp.fao.org. Accessed 1 March 2007. FAOSTAT 2013. http://faostat.fao.org/site/339/default.aspx

GAD, A.S., KHOLIF, A.M., SAYED, A.F. 2010. Evaluation of the nutritional value of functional yoghurt resulting from combination of date palm syrup and skim milk. American $J$ Food Tech. 5:250259. http://dx.doi.org/10.3923/ajft.2010.250.259

HUSSEIN, G.A.M. 2010. Preparation of yoghurt and probiotic yoghurt- like fermented products for bottle-fed infants. Egyptian J. Dairy Sci., 38:171-182.

KALE, R.V., KADAM, P.S., HASHMI, S.I. (2011). Effect of different varieties of date palm past incorporation on quality characteristics of yoghurt. Carpathian $J$ Food Sci., and Tech. 3:28-38.

KEHAGIAS, C., KOULOURIS, S., ARKOUDELOS, J.S., SAMONA, A. 2006 Viability and bio-chemical activity of Bifidobacteria in association with yoghurt starter cultures in Bifidus milk and bio-yoghurt during storage at $4^{\circ} \mathrm{C}$. Egyptian J. Dairy Sci., 34:151-158.

KESHTKARAN, M., MOHAMMADIFAR, M.A. 2013. The Effects of date syrup and gum tragacanth on physical and rheological properties of date milk beverage. World J Dairy \& Food Sciences 8: 147-155.

KOSIKOWSKI, F.V. 1978. Cheese and Fermented Milk Foods. 2nd ${ }^{\text {ed }}$. Cornell Univ. Ithaca, New York.

LING, E.R. 1963. A Text - Book of Dairy Chemistry. Vol. 2, Practical, $3^{\text {rd }}$ ed. Champan and Hall, London, England.

MANSOURI, A., EMBARED, G., KOKKALOU, E., KEFALAS, P. 2005. Phenolic profile and antioxidant activity of the Algerian ripe date palm fruit (Phoenix dactylifera). Food Chem., 89:411420. http://dx.doi.org/10.1016/j.foodchem.2004.02.051

MATTILA-SANDHOLM, T., MYLLARINEN, P., CRITTENDEN, R., MOGENSEN, G., FONDEN, R., SAARELA, M. 2002. Technological challenges for future probiotic foods. Int. Dairy J. 12:173182. http://dx.doi.org/10.1016/s0958-6946(01)00099-1

MEHANNA, N.M., MEHANNA, A. S. 1989. Studies on the use of stabilizer for improving some properties of cow's milk yoghurt. Egyptian J. Dairy Sci. $17: 289$

MILLER, C.J. DUNN, E.V., HASHIM, I.B. 2003. The glycaemic index of dates and date/yoghurt mixed meals. Are dates the candy that grows on trees? Eur. J. Clin. Nutr., 57:427-430. http://dx.doi.org/10.1038/sj.ejcn.1601565

MORRIS, J.G. 2000. The effect of redox potential. In Lund, B.M., Baird-Parker, T.C., \& Gould, G.W. (Ed.), The microbiological safety and quality of food, Vol. 1. (pp. 235-250).

NOURI1, M., EZZATPANAH, H., ABBASI, S. 2011. Application of renneted skim milk as a fat mimetics in nonfat yoghurt. Food and Nutrition Sci., 2:541548. http://dx.doi.org/10.4236/fns.2011.26077

PURI, A., SAHAI, R., SINGH, K.L., SAXENA, R.P., TANDON, J.S., SAXENA, K.C. 2000. Immunostimulant activity of dry fruits and plant materials used in Indian traditional medical system for mother after child birth and invalids. J. Ethnopharmacol., 71:89-92. http://dx.doi.org/10.1016/s03788741(99)00181-6

ROUTRAY, W., MISHRA, H.N. 2011. Scientific and technical aspects of yoghurt aroma and taste; a review. Compr Rev Food Sci Fd Safety.10:208210. http://dx.doi.org/10.1111/j.1541-4337.2011.00151.x

SACCARO, D.M., TAMIME, A.Y.; PILLEGGI, A.O.P.S., OLIVEIRA, M.N 2009. The viability of three probiotic organisms grown with yoghurt starter cultures during storage for 21 days at $4^{\circ} \mathrm{C}$. Int. J. of Dairy Tech. 62:397-

404. http://dx.doi.org/10.1111/j.1471-0307.2009.00497.x

SAS 1991. SAS User's guide: statistics. SAS Inst, Inc, Cary, NC.

SHAH, N.P. 2000. Probiotic bacteria: Selective enumeration and survival in dairy foods. J. Dairy Sci. 83, 894-907. http://dx.doi.org/10.3168/jds.s00220302(00)74953-8

SHIHATA, A., SHAH. N.P. 2002. Influence of addition of proteolytic strains of Lactobacillus delbrueckii subsp. bulgaricus to commercial ABT starter cultures on texture of yoghurt, exopolysaccharide production and survival of bacteria. Int. Dairy J. 12:765-772. http://dx.doi.org/10.1016/s0958-6946(02)00071-7 
TAMIME, A.Y., ROBINSON, R.K. 1999. Yoghurt Science and Technology, $2^{\text {nd }}$ ed., CRC Press LLC, Washington, DC. http://dx.doi.org/10.1111/j.14710307.1999.tb02857.x

TAMIMEA, A.Y., BARCLAYA, M.N.I., McNULTY, D., O'CONNOR, T.P 1999. Kishk-a dried fermented milk/cereal mixture. 3. Nutritional composition. Lait, 79:435-448. http://dx.doi.org/10.1051/lait:1999436

TAMMAM, A.A., MANSOUR, A.I A., SALMAN, K.H., EL-GAZZAR, F.H.

2013. Preparation, and properties of bio-yoghurt containing date syrup (dibis). Egyptian J. Dairy Sci., 41:69-76.

THE DAIRY COUNCIL. 2007. Minerals in yoghurt.

http://www.milk.co.uk/page.aspx?intPageID=84 (accessed June 2007)

THOMAS, T.D., PRITCHARD. G.G. 1987. Proteolytic enzymes of dairy starter cultures. FEMS Microbiol. Rev. 46:245-268. http://dx.doi.org/10.1111/j.15746968.1987.tb02464.x

VASILJEVIC, T. SHAH N.P. 2008. Probiotics - from Metchnikoff to bioactives. International Dairy $J, \quad 18$ : 728. http://dx.doi.org/10.1016/j.idairyj.2008.03.004

YOUSEF, M., NATEGHI1, L., AZADI, E. 2013. Effect of different concentration of fruit additives on some physicochemical properties of yoghurt during storage. Annals of Biological Research, 4 (4):244-249.

YOUSIF, A.K. 1995. Processing, shelf-life and evaluation of plain and chocolate coated date bars. Food Sci. \& Technol. Today, 8 (4), 243-245.

ZHENG, W., WANG, S.Y. 2001. Antioxidant activity and phenolic compounds in selected herbs. J. Agric. Food Chem., 49:5165-5170. http://dx.doi.org/10.1021/jf010697n 